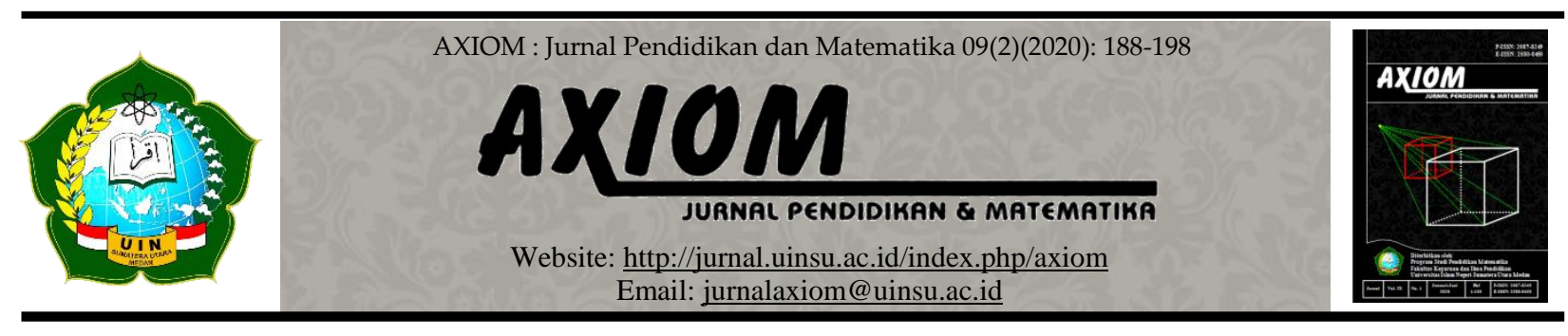

\title{
PERBEDAAN HASIL BELAJAR MAHASISWA YANG DIAJARKAN DENGAN MODEL PEMBELAJARAN KOOPERATIF TIPE JIGSA W DAN MODEL PEMBELAJARAN LANGSUNG
}

\author{
Oleh:
}

\author{
Tanti Jumaisyaroh Siregar \\ Dosen Tetap Program Studi Pendidikan Matematika, FITK,UINSU Medan \\ E-mail: tantijumaisyaroh@uinsu.ac.id
}

doi : 10.30821/axiom.v9i2.8078

\begin{abstract}
Abstrak:
Adapun tujuan dari penelitian ini yaitu untuk mengetahui perbedaan hasil belajar mahasiswa yang diajarkan dengan pembelajaran kooperatif tipe jigsaw dengan mahasiswa yang diberi pembelajaran langsung. Penelitian ini merupakan salah satu jenis penelitian kuantitatif dengan menggunakan model kuasi eksperimen dengan pre test-post test control group design. Populasi dalam penelitian ini meliputi seluruh mahasiswa pendidikan matematika salah satu universitas yang berada di Medan. Sampel dalam penelitian ini melibatkan mahasiswa semester IV sebanyak 42 orang pada kelas eksperimen dan 41 orang pada kelas kontrol yang diambil secara acak menggunakan cluster random sampling. Jenis data dalam penelitian ini adalah data kuantitatif. Instrumen yang digunakan untuk memperoleh data dalam penelitian ini adalah tes hasil belajar pada mata kuliah metode numerik yang berbentuk essay test. Data dianalisis dengan menggunakan statistik inferensial menggunakan uji-t. Berdasarkan hasil analisis data diperoleh nilai sig $=0.00001<\alpha=0,05$ sehingga $\mathrm{H}_{\mathrm{o}}$ ditolak dan $\mathrm{H}_{\mathrm{a}}$ diterima yang berarti terdapat perbedaan hasil belajar pada mata kuliah metode numerik antara mahasiswa yang diberi pembelajaran kooperatif tipe jigsaw dibandingkan dengan mahasiswa yang diberi pembelajaran langsung. Oleh karena itu, dapat disimpulkan rata-rata hasil belajar metode numerik mahasiswa yang memperoleh pembelajaran kooperatif tipe jigsaw lebih tinggi secara signifikan dibandingkan dengan mahasiswa yang memperoleh pembelajaran langsung. Oleh karena itu, disarankan model pembelajaran kooperatif tipe jigsaw dapat digunakan sebagai alternatif untuk dosen matematika dalam meningkatkan hasil belajar metode numerik mahasiswa.
\end{abstract}

\section{Kata Kunci :}

Hasil Belajar, Pembelajaran Kooperatif, Jigsaw.

\section{Abstract:}

The purpose of this study is to determine the differences in student learning outcomes taught by the type of jigsaw cooperative learning with students who are given direct learning. This research is one type of quantitative research using a quasi-experimental model with a pre-test-post-test control group design. The population in this study included all mathematics education students at a university in Medan. The sample in this study involved 42 semester IV students in the experimental class and 41 people in the control class who were taken randomly using cluster random sampling. The type of data in this research is quantitative data. The instrument used to obtain data in this study was a learning outcome test in a numerical method subject in the form of 
an essay test. Data were analyzed using inferential statistics using t-test. Based on the results of data analysis, the value of sig $=0.00001<\alpha=0.05$ so that Ho is rejected and Ha is accepted, which means that there are differences in student learning outcomes of the numerical method between students who are given the jigsaw type of cooperative learning compared to students who are given direct learning. Therefore, it can be concluded that the average learning outcomes of the numerical method of students who get the jigsaw type of cooperative learning are significantly higher than students who receive direct learning. Therefore, it is suggested that the jigsaw type of cooperative learning model can be used as an alternative for mathematics lecturers in improving student learning outcomes in numerical methods.

\section{Keywords:}

Learning Outcomes, Cooperative Learning, Jigsaw.

\section{A. Pendahuluan}

Salah satu tujuan diselenggarakannya pendidikan di perguruan tinggi menurut UU No.12 Tahun 2012 pasal 5 tentang Perguruan Tinggi yaitu ingin menghasilkan lulusan yang dapat menguasai cabang ilmu pengetahuan dan teknologi untuk memenuhi kepentingan nasional dan daya saing bangsa. Indikator pencapaian tujuan pendidikan tersebut salah satunya melalui evaluasi hasil belajar mahasiswa. Hasil belajar merupakan acuan dalam mengukur kemampuan mahasiswa dalam memahami fakta, konsep, prinsip dan kemampuannya mulai dari pengertian sampai pemecahan masalah (Nurfitriyanti, 2017:156). Selanjutnya, Muin dan Ulfah (2012:75) menyatakan bahwa hasil belajar merupakan perubahan yang diperoleh oleh mahasiswa setelah mengikuti serangkaian kegiatan belajar. Jadi, dapat dinyatakan hasil belajar mahasiswa merupakan penilaian yang diberikan oleh dosen terhadap kemampuan mahasiswa dalam setelah selesai mengikuti proses pembelajaran. Hasil belajar menurut Bloom dapat dibedakan atas tiga ranah yaitu kognitif, afektif dan psikomotorik (Sudjana, 2010:22). Ranah kognitif terdiri atas intelektual dan kemampuan berpikir mahasiswa, ranah afektif mencakup segala yang berkaitan dengan emosi dan sikap mahasiswa serta ranah psikomotorik meliputi gerakan dan keterampilan motorik mahasiswa. Peneliti berfokus pada ranah kognitif (pengetahuan) mahasiswa khususnya pada mata kuliah metode numerik dalam penelitian ini.

Hasil belajar sangat penting dalam pelaksanaan kegiatan pembelajaran. Hal ini dikarenakan hasil belajar merupakan indikator keberhasilan bagi dosen atau dosen dalam membelajarkan mahasiswa (Wibowo \& Farnisa, 2018: 183). Indikator tersebut bermakna agar dosen dapat terus menerus memperbaiki praktik pembelajarannya di kelas. Selain itu, menurut Baharun (2015: 39) adanya hasil belajar mahasiswa dapat mengetahui kemampuan-kemampuan yang dimiliki mahasiswa setelah ia memperoleh pengalaman belajarnya. Hal tersebut berarti hasil belajar dapat memberikan stimulus dan motivasi mahasiswa untuk terus meningkatkan hasil belajarnya. Namun, pentingnya hasil belajar tersebut belum sesuai dengan kenyataan yang terjadi di lapangan dimana hasil belajar mahasiswa mahasiswa khususnya mahasiswa prodi pendidikan matematika pada mata kuliah metode numerik masih menunjukkan hasil yang belum maksimal. Pernyataan tersebut didukung dengan data hasil belajar mahasiswa dimana masih banyak mahasiswa yang memperoleh nilai di bawah 70 pada saat Ujian Tengah Semester (UTS). Hal ini menunjukkan hasil belajar mahasiswa pada mata kuliah metode numerik masih rendah.

Hasil belajar mahasiswa yang masih rendah dipengaruhi oleh beberapa faktor dimana salah satunya dipengaruhi oleh kegiatan pembelajaran yang dilakukan oleh dosen. Hal ini sesui dengan pernyataan Yulianti dan Fitri (2017: 243) bahwa model pembelajaran yang diterapkan oleh dosen selama kegiatan perkuliahan seringkali mempengaruhi pemahaman mahasiswa terhadap materi perkuliahan yang diberikan. Fakta di lapangan menunjukkan bahwa kebanyakan dosen masih menerapkan pembelajaran yang berpusat kepada dosen seperti pembelajaran langsung. Model pembelajaran langsung merupakan pembelajaran yang mana pendidik menyampaikan materi kepada peserta didik dengan langkah-langkah sederhana dan sistematis (Susiaty, 2017: 35-36). Dalam hal ini, model pembelajaran langsung cocok digunakan untuk mengajarkan pengetahuan dasar yang bersifat konsep dan prosedur. Selanjutnya, pembelajaran 
langsung merupakan model pembelajaran yang terpusat pada dosen yang disajikan dalam lima tahap yaitu (1) menyampaikan tujuan pembelajaran, (2) mendemonstrasikan pengetahuan dan keterampilan, (3) memberikan latihan terbimbing, (4) memberikan umpan balik dan (5) memberikan kesempatan pada pelatihan lanjutan (Asmah, 2018: 111). Pada model pembelajaran ini pembelajaran lebih didominasi oleh dosen dimana dosen sebagai sumber belajar utama. Hal ini yang diduga membuat hasil belajar mahasiswa belum sesuai dengan yang diharapkan.

Salah satu cara untuk mengatasi permasalahan tersebut, penulis menerapkan model pembelajaran kooperatif tipe jigsaw. Model pembelajaran kooperatif tipe jigsaw merupakan model pembelajaran yang dapat membentuk mahasiswa untuk berpikir secara aktif dan kreatif dalam proses pembelajaran. Penggunaan model pembelajaran ini juga efektif dalam mengurangi monopoli dosen dalam penguasaan jalannya proses pembelajaran, dan kebosanan siswa dalam menerima pelajaran akan berkurang. Selanjutnya, model pembelajaran ini juga dapat mengembangkan seluruh potensi yang ada termasuk emosional dan keterampilan mahasiswa (Lie, 2010: 69). Selain itu, menurut Astuti \& Abadi (2015: 237) pada pembelajaran kooperatif tipe jigsaw memungkinkan mahasiswa untuk dapat saling berdiskusi, berpikir, mengemukakan pendapat dan menganalisis pendapat teman sehingga dapat meningkatkan kemampuan berpikir tingkat tinggi mahasiswa. Jika kemampuan berpikir, emosional dan keterampilan mahasiswa meningkat, maka hasil belajar mahasiswa pun juga dapat meningkat

Hal tersebut juga didukung oleh hasil penelitian terdahulu terkait penerapan model pembelajaran jigsaw dan pembelajaran langsung seperti Katili (2017), Wahyuningsih, Rezeki, \& Zetriuslita (2013) dan Handayani (2018) yang menyatakan bahwa terdapat perbedaan yang signifikan rata-rata hasil belajar mahasiswa yang diajar dengan menerapkan model pembelajaran kooperatif tipe jigsaw dan pembelajaran langsung. Jadi, melalui penerapan model pembelajaran kooperatif tipe jigsaw diharapkan dapat meningkatkan hasil belajar mahasiswa. Berdasarkan penjelasan diatas, maka peneliti tertarik untuk melakukan penelitian dengan judul "Perbedaan Hasil Belajar Mahasiswa yang Diajarkan dengan Model Pembelajaran Kooperatif Tipe Jigsaw dan Model Pembelajaran Langsung”.

\section{B. Kajian Teoritis}

Berikut ini akan dijelaskan mengenai teori sebagai dasar dalam penyusunan hipotesis dalam penelitian ini meliputi hasil belajar, model pembelajaran kooperatif tipe jigsaw dan model pembelajaran langsung.

\section{Hasil Belajar}

Hasil belajar merupakan salah satu output yang diperoleh oleh siswa setelah proses pembelajaran selesai dilaksanakan di kelas. Hal yang sama diungkapkan oleh Susanto (2013: 5) bahwa hasil belajar merupakan perubahan yang terjadi pada diri mahasiswa sebagai hasil dari kegiatan proses pembelajaran. Dalam hal ini perubahan yang dimaksud berbentuk perubahan perilaku mahasiswa yang sifatnya menetap. Abdullah (2015: 169) menyatakan bahwa hasil belajar merupakan hasil yang diperoleh oleh mahasiswa setelah memperoleh pengalaman belajar dan mengalami perubahan. Hasil belajar disini juga berarti kapabilitas yang dimiliki oleh mahasiswa setelah mengikuti kegiatan pembelajaran dan adanya perubahan ke arah yang positif.

Rosdiati (2017: 316) yang menyatakan bahwa hasil belajar merupakan kemampuan yang dicapai oleh mahasiswa setelah mengikuti kegiatan belajar yang dinyatakan dalam bentuk angka atau skor. Menurut Yusuf (2017: 181) bahwa hasil belajar merupakan bentuk pencapaian mahasiswa dalam proses pembelajaran. Hasil belajar disini merupakan simbol keberhasilan seorang dosen dalam membelajarkan mahasiswanya. Berdasarkan beberapa penjelasan di atas, dapat disimpulkan bahwa hasil belajar merupakan keberhasilan yang dicapai oleh mahasiswa dalam proses belajar yang dapat diukur dalam bentuk skor atau angka.

Ketercapaian hasil belajar dengan tujuan belajar yang telah ditetapkan menurut Susanto (2013: 6) dapat dilihat dari beberapa aspek yaitu aspek kognitif (pemahaman konsep), afektif (sikap) dan psikomotorik (keterampilan proses). Penelitian ini lebih berfokus pada aspek kognitif 
mahasiswa. Adapun kategori hasil belajar kognitif mahasiswa meliputi mengingat, memahami, menerapkan, menganalisis, mengevaluasi dan mencipta (Anderson et al., 2001: 66-88). Keenam kategori tersebutlah yang digunakan dalam penelitian ini sebagai acuan dalam penyusunan tes hasil belajar mahasiswa.

\section{Model Pembelajaran Kooperatif Tipe Jigsaw}

Model pembelajaran kooperatif tipe jigsaw merupakan salah satu jenis model pembelajaran kooperatif. Menurut Isjoni (2010: 78) bahwa model pembelajaran kooperatif tipe jigsaw merupakan salah satu jenis pembelajaran kooperatif yang mendorong mahasiswa untuk aktif dan saling berkerjasama dalam mempelajari suatu materi. Kegiatan pembelajaran jigsaw disini dapat menciptakan sikap ketergantungan positif, bertanggung jawab dan mandiri dalam anggota setiap kelompok. Model Pembelajaran kooperatif tipe jigsaw merupakan pembelajaran yang membagi mahasiswa ke dalam kelompok heterogen yang terdiri atas 5-6 orang mahasiswa yang betanggungjawab untuk menguasai suatu materi dan mengajarkannya kepada anggota kelompok lainnya (Arends, 2012:13). Kelompok yang heterogen disini berarti terdapat perbedaan anggota kelompok dari segi kemampuan, jenis kelamin, agama, suku dan sebagainya. Hal yang sama juga dinyatakan oleh Yamin (2013 : 90) bahwa pembelajaran kooperatif tipe jigsaw adalah penerapan kerjasama masing-masing mahasiswa dalam suatu kelompok dengan kemampuan yang heterogen dan setiap anggota kelompok bertanggung jawab atas salah satu bagian materi. Pada pembelajaran ini setiap anggota kelompok diberi bagian materi tertentu dan menjadi pakar (expert) pada bagian materi tersebut. Menurut Mashudi (2018: 159) bahwa model pembelajaran jigsaw adalah salah satu jenis pembelajaran kooperatif yang terdiri dari beberapa orang dalam suatu kelompok dan setiap anggota kelompok bertanggung jawab atas penguasaan bagian materi belajar dan dapat mengajarkan materi tersebut kepada anggota kelompok yang lainnya. Berdasarkan penjelasan di atas, dapat disimpulkan bahwa model pembelajaran jigsaw merupakan jenis pembelajaran kooperatif yang terdiri atas kelompok mahasiswa yang heterogen khususnya dari segi kemampuan dimana setiap anggota kelompok diberi tanggungjawab sebagai tim ahli dalam menjelaskan materi bagiannya kepada anggota kelompok asalnya masing-masing.

Adapun langkah-langkah pembelajaran kooperatif tipe jigsaw yang diterapkan dalam penelitian ini yaitu yaitu: (a) Dosen membagi topik pembelajaran menjadi beberapa subtopik dimana dosen telah memberitahu terlebih dahulu topik yang akan dibahas; (b) Dosen membagi mahasiswa kedalam beberapa kelompok; (c) Dosen membagikan masing-masing topik kepada masing-masing kelompok; (d) Setiap kelompok memberikan tugas kepada anggota kelompoknya untuk mempelajari sub topik tertentu; (e) Dosen meminta masing-masing kelompok mempelajari topik tersebut; (f) Mahasiswa yang mendapat subtopik yang sama dari masing-masing kelompok saling berkumpul untuk mendiskusikan subtopik tersebut; (g) Setelah setiap kelompok yang ditugaskan mempelajari sub topik tertentu selesai berdiskusi maka mereka kembali kepada kelompok asalnya untuk menjelaskan materi kepada teman sekelompoknya secara bergantian dan (h) dosen memberikan mahasiswa kuis yang dikerjakan individu (Arends, 2012: 13-14).

\section{Model Pembelajaran Langsung}

Pembelajaran langsung merupakan salah satu jenis pembelajaran yang paling sering digunakan oleh dosen-dosen pada saat melaksanakan perkuliahan di kelas. Menurut Suyatno (2009: 73) bahwa pembelajaran langsung merupakan suatu pendekatan pengajaran yang dapat membantu mahasiswa untuk memperoleh informasi yang dapat diajarkan tahap demi tahap. Pengetahuan yang bersifat informasi akan lebih efektif jika disampaikan dengan cara pembelajaran langsung. Pembelajaran langsung adalah suatu pembelajaran yang bersifat berpusat pada dosen (teacher center) atau pembelajaran yang menekankan pada dominasi dosen (Riyanto, 2010: 280). Pembelajaran ini sering juga disebut dengan pembelajaran yang berpusat pada dosen. 
Menurut Trianto (2011:41) juga menyatakan bahwa pembelajaran langsung merupakan salah satu pembelajaran yang dirancang khusus untuk menunjang proses belajar mahasiswa yang berkaitan dengan pengetahuan deklaratif dan pengetahuan prosedural yang terstruktur dengan baik yang dapat diajarkan dengan pola kegiatan yang bertahap selangkah demi selangkah. Hal yang sama juga dinyatakan oleh Arends (2012: 294) pembelajaran langsung adalah pembelajaran yang digunakan untuk membantu mahasiswa mempelajari mempelajari pengetahuan dasar berupa pengetahuan konseptual yang dapat diajarkan dengan secara langkah demi langkah. Jadi, berdasarkan beberapa pendapat ahli di atas maka dapat disimpulkan bahwa pembelajaran langsung adalah pembelajaran yang berpusat pada dosen yang dirancang untuk membantu mahasiswa belajar pengetahuan dasar dengan cara bertahap.

Sintaks pembelajaran langsung yang diterapkan dalam penelitian ini adalah sebagai berikut: (1) Dosen menjelaskan TPK, informasi latar belakang pentingnya pelajaran, mempersiapkan mahasiswa untuk belajar; (2) Dosen mendemonstrasikan keterampilan dengan benar, atau menyajikan informasi tahap demi tahap; (3) Dosen merencanakan dan memberi bimbingan pelatihan awal; (4) Mengecek apakah mahasiswa telah berhasil melakukan tugas dengan baik, memberi umpan balik; (5) Dosen mempersiapkan kesempatan melakukan pelatihan lanjutan, dengan perhatian khusus pada penerapan kepada situasi lebih kompleks (Trianto, 2011: 43).

\section{Metode Penelitiaan}

Berikut ini akan dijelaskan lebih detail terkait metode dalam penelitian ini.

\section{Jenis penelitian}

Penelitian ini merupakan salah satu jenis penelitian kuantitatif dengan menggunakan model kuasi eksperimen dengan desain kelompok pre test-post test control group design yang bertujuan untuk mengetahui perbedaan hasil belajar mahasiswa yang diajarkan dengan model pembelajaran kooperatif tipe jigsaw dan model pembelajaran langsung. Pada penelitian ini terdapat dua kelompok dimana sampel yang diberikan perlakuan(pembelajaran kooperatif tipe jigsaw) disebut kelompok eksperimen, sedangkan kelompok yang tidak mendapatkan perlakuan disebut kelompok kontrol (pembelajaran langsung). Penelitian ini menggunakan desain penelitian sebagai berikut (Arikunto, 2010: 210):

Kelompok Eksperimen $0_{1} \mathrm{X} \quad 0_{2}$

Kelompok Kontrol $\quad 0_{1} \quad 0_{2}$

Keterangan :

$\mathrm{X}=$ Perlakuan berupa pembelajaran kooperatif tipe jigsaw

$0_{1}=$ Pre test hasil belajar mahasiswa

$\mathrm{O}_{2}=$ Post test hasil belajar mahasiswa

\section{Waktu dan Tempat Penelitian}

Penelitian ini dilaksanakan pada semester genap tahun ajaran 2018/2019 pada bulan Mei 2019 sampai Juli 2019. Penelitian Ini dilaksanakan pada salah satu Universitas yang berada di Medan.

\section{Populasi dan Sampel}

Populasi dalam penelitian ini meliputi seluruh mahasiswa prodi pendidikan matematika salah satu universitas yang berada di Medan pada mata kuliah metode numerik. Sampel dalam penelitian ini melibatkan mahasiswa semester IV yang terdiri dari dua kelas, yaitu kelas eksperimen sebanyak 42 orang dan kelas kontrol sebanyak 41 orang. Kedua kelas sampel ini dipilih secara acak menggunakan cluster random sampling.

\section{Prosedur}

Prosedur yang dilakukan dalam penelitian ini adalah sebagai berikut : 
a. Studi pendahuluan

Kegiatan yang dilakukan yaitu merumuskan identifikasi masalah, rumusan masalah, studi literarur dan pengembangan perangkat penelitian berupa bahan ajar (materi), serta instrumen penelitian (tes hasil belajar) kemudian perangkat pembelajaran serta instrumen penelitian diberikan kepada validator untuk diperiksa terkait dengan penulisan, penyusunan dan bahasa kalimat yang selanjutnya dinilai apakah perangkat pembelajaran serta instrumen penelitian layak atau tidak untuk diujicobakan kepada mahasiswa.

b. Penentuan populasi dan sampel penelitian

Berdasarkan populasi kelas yang ada maka dipilih dua kelas masing-masing terdiri dari satu kelas eksperimen dan satu kelas kontrol. Kelas yang terpilih sebagai kelas eksperimen diberi perlakuan berupa pembelajaran kooperatif tipe jigsaw sedangkan kelas yang terpilih sebagai kelas kontrol diajar dengan pembelajaran langsung.

c. Pemberian Soal Pre Test pada Kedua Sampel Penelitian

Kedua sampel yaitu mahasiswa pada kelas kontrol dan kelas eksperimen diberikan soal pre test hasil belajar mahasiswa untuk melihat kemampuan mahasiswa sebelum diberi pengajaran.

d. Penerapan Model Pembelajaran

Setelah pemberian pre test maka diterapkan pembelajaran kooperatif tipe jigsaw di kelas eksperimen dan pembelajaran langsung diterapkan pada kelas kontrol selama 8 minggu.

e. Pemberian Soal Post Test pada Kedua Sampel Penelitian

Pada akhir pertemuan kedua kelas baik kelas eksperimen maupun kelas kontrol diberikan soal post test hasil belajar mahasiswa untuk diselesaikan oleh mahasiswa sehingga diperoleh data hasil belajar mahasiswa.

f. Analisis Data dan Penulisan Laporan

Data hasil belajar mahasiswa yang telah diperoleh diperiksa, diberi skor, disusun, diolah dan dianalisis dengan menggunakan analisis statistik yang sudah direncanakan sebelumnya yaitu berupa uji normalitas, uji homogenitas, uji t sehingga diperoleh beberapa hasil dalam pelaksanaan penelitian. Hasil penelitian yang ada ditulis ke dalam laporan yang berisi deskripsi hasil penelitian, pengujian hipotesis dan pembahasan pada saat penelitian serta dibuat kesimpulan terkait dengan hasil yang diperoleh dalam pelaksanaan penelitian.

\section{Data, Instrumen dan Teknik Pengumpulan Data}

Jenis data dalam penelitian ini adalah data kuantitatif. Instrumen yang digunakan untuk memperoleh data dalam penelitian ini adalah tes hasil belajar dalam mata kuliah metode sebanyak sebanyak 5 soal berbentuk essay test. Seluruh butir soal tes dinyatakan valid dan memiliki derajat reliabillitas tinggi berdasarkan hasil uji coba.Teknik yang digunakan untuk mengumpulkan data dalam penelitian ini yaitu dengan memberikan tes hasil belajar kepada mahasiswa di kelas eksperimen dan kelas kontrol.

\section{Teknis Analisis Data}

Data dianalisis dengan menggunakan statistik inferensial dalam melakukan pengujian terhadap hipotesis, Sebelum dilakukan pengujian hipotesis maka dilakukan terlebih dulu uji prasyarat yaitu uji normalitas dan homogenitas terhadap skor post test hasil belajar baik di kelas eksperimen maupun kelas kontrol. Jika uji prasyarat sudah terpenuhi maka selanjutnya dilakukan pengujian hipotesis menggunakan uji-t.

\section{Hasil Penelitian dan Pembahasan}

Berikut ini akan dijelaskan secara detail mengenai hasil dan pembahasan penelitian ini.

\section{Hasil}

Berdasarkan hasil analisis deskriptif terhadap data pre test hasil belajar mahasiswa yang diberikan pada kelas eksperimen (pembelajaran kooperatif tipe jigsaw) diperoleh nilai nilai 
minimum 45, maksimum 65 , rata-rata 56,90 dan standar deviasi 5,733. Selanjutnya, data hasil pre test hasil belajar mahasiswa pada kelas kontrol (pembelajaran langsung) diperoleh nilai nilai minimum 45, maksimum 65, rata-rata 56,95 dan standar deviasi 4,857. Rata-rata hasil pre test pada kelas kontrol hanya 0,05 lebih tinggi dibandingkan kelas eksperimen. Hal ini menunjukkan bahwa kedua kelas memiliki kemampuan awal yang sama. Selanjutnya, standar deviasi pada kelas kontrol lebih besar daripada kelas eksperimen dengan selisih 0,876 yang menandakan data kelas kontrol lebih menyebar dan memiliki kecenderungan setiap data berbeda satu sama lain. Berikut data pre test hasil belajar mahasiswa baik di kelas eksperimen maupun di kelas kontrol yang dinyatakan dalam tabel di bawah ini.

Tabel 1. Data Pre Test Hasil Belajar Mahasiswa di Kelas Eksperimen dan Kelas Kontrol

\begin{tabular}{lcccc}
\hline \multicolumn{1}{c}{ Kelas } & $\boldsymbol{X}_{\text {min }}$ & $\boldsymbol{X}_{\text {maks }}$ & Rata-rata & $\begin{array}{c}\text { Standar } \\
\text { Deviasi }\end{array}$ \\
\hline Eksperimen & 45 & 65 & 56,90 & 5,733 \\
Kontrol & 45 & 65 & 56,95 & 4,857 \\
\hline
\end{tabular}

Hasil analisis deskriptif untuk data post test hasil belajar mahasiswa yang diberikan pada kelas eksperimen diperoleh nilai minimum 75 , nilai maksimum 90 , rata-rata 81,43 dan standar deviasi 5,213. Selanjutnya, pada data post test hasil belajar mahasiswa pada kelas kontrol diperoleh nilai minimum 60, nilai maksimum 85, nilai rata-rata 67,32 dan standar deviasi 6,528. Rata-rata hasil post test pada kelas eksperimen lebih tinggi 14,11 lebih tinggi dibandingkan kelas kontrol. Selanjutnya, standar deviasi pada kelas eksperimen lebih besar daripada kelas kontrol dengan selisih 1,315 yang menandakan data kelas eksperimen lebih menyebar dan memiliki kecenderungan setiap data berbeda satu sama lain. Berdasarkan nilai rata-rata tersebut diperoleh bahwa nilai rata-rata kedua kelas sampel tersebut berbeda dimana rerata hasil post test pada kelas eksperimen lebih tinggi dibandingkan kelas kontrol. Data post test hasil belajar pada kedua sampel dapat dilihat lebih jelas pada tabel ini.

Tabel 2. Data Post Test Hasil Belajar Mahasiswa di Kelas Eksperimen dan Kelas Kontrol

\begin{tabular}{lcccc}
\multicolumn{1}{c}{ Kelas } & $\boldsymbol{X}_{\text {min }}$ & $\boldsymbol{X}_{\text {maks }}$ & Rata-rata & $\begin{array}{c}\text { Standar } \\
\text { Deviasi }\end{array}$ \\
\hline Eksperimen & 75 & 90 & 81,43 & 5,213 \\
Kontrol & 60 & 85 & 67,32 & 6,528 \\
\hline
\end{tabular}

Selanjutnya, akan dilakukan pengujian hipotesis terhadap data post test hasil belajar mahasiswa baik di kelas eksperimen maupun di kelas kontrol dengan menggunakan uji-t. Namun, sebelum dilakukan pengujian hipotesis maka akan dilakukan uji pra syarat yaitu uji normalitas dan uji homogenitas. Uji normalitas data pada penelitian ini dengan menggunakan uji Kolmogorov-Smirnov. Hasil uji normalitas data baik pada kelas eksperimen maupun kelas kontrol dapat dilihat pada tabel berikut.

\section{Tabel 3. Hasil Uji Normalitas Data Post Tes Hasil Belajar Mahasiswa pada Kelas Eksperimen dan Kelas Kontrol}

\begin{tabular}{lcccc}
\hline & Pembelajaran & \multicolumn{3}{c}{ Kolmogorov-Smirnov $^{\mathbf{a}}$} \\
& & Statistic & df & Sig. \\
\hline \multirow{2}{*}{ Nilai Post Test } & Eksperimen & .18543 & 42 & .10051 \\
& Kontrol & .18882 & 41 & .094 \\
\hline
\end{tabular}

Dari hasil uji Kolmogorov-Smirnov test tersebut, diketahui bahwa nilai signifikansi kelas eksperimen sebesar 0,18543dan kelas kontrol 0,094 karena nilai signifikansi kelas eksperimen 
dan kelas kontrolyaitu 0.1853 dan $0,094>\alpha: 0,05$ maka data post test hasil belajar mahasiswa kelas eksperimen dan kelas kontrol berdistribusi normal. Dengan demikian, dapat disimpulkan bahwa data post test hasil belajar mahasiswa secara keseluruhan berdistribusi normal. Setelah melalui tahap uji normalitas, data $\mathrm{N}$-gain juga harus melalui tahap uji homogenitas. Pada penelitian ini uji homogenitas menggunakan uji Levene pada nilai post test hasil belajar mahasiswa baik pada kelas eksperimen maupun pada kelas kontrol. Hasil uji homogenitas pada kedua sampel dapat dilihat lebih jelas pada tabel di bawah ini.

\section{Tabel 4. Hasil Uji Normalitas Data Post Tes Hasil Belajar Mahasiswa pada Kelas Eksperimen dan Kelas Kontrol}

\begin{tabular}{cccc}
\hline Levene Statistics Post_Test & df 1 & df 2 & Sig. \\
\hline 3.4694 & 1 & 81 & 0.66138 \\
\hline
\end{tabular}

Dari hasil uji Levene tersebut, diketahui bahwa nilai signifikansinya sebesar $0,0661>\alpha$ : 0,05 sehingga hipotesis nol diterima yang berarti semua populasi mempunyai varians yang sama/homogen. Dengan demikian, data post test hasil belajar mahasiswa secara keseluruhan dapat disimpulkan memiliki varians yang sama atau homogen. Berdasarkan pengujian normalitas dan homogenitas di atas disimpulkan bahwa data post test hasil belajar mahasiswa kedua sampel baik pada kelas eksperimen maupun kelas kontrol berdistribusi normal dan memiliki varians yang sama atau homogen. Dari hasil uji prasyarat analisis yakni uji normalitas dan homogenitas menunjukkan bahwa data data post test hasil belajar mahasiswa berdistribusi normal dan homogen, maka untuk menganalisisnya menggunakan uji statistik parametrik yakni menggunakan uji t.

Berdasarkan hasil perhitungan, dengan menggunakan uji t pada taraf signifikansi $\alpha=$ 0,05 diperoleh dapat diketahui bahwa nilai $\mathrm{F}$ pada faktor pembelajaran (pembelajaran kooperatif tipe jigsaw dan pembelajaran langsung) dengan nilai signifikansi 0,00001 lebih kecil dari taraf signifikansi 0,05 sehingga $\mathrm{H}_{\mathrm{o}}$ ditolak. Dengan kata lain, terdapat perbedaan hasil belajar mahasiswa antara mahasiswa yang diberi pembelajaran kooperatif tipe jigsaw dibandingkan dengan mahasiswa yang diberi pembelajaran langsung. Oleh karena itu, dapat disimpulkan ratarata hasil belajar mahasiswa yang memperoleh pembelajaran kooperatif tipe jigsaw lebih tinggi secara signifikan dibandingkan dengan mahasiswa yang memperoleh pembelajaran langsung.

\section{Pembahasan}

Dari hasil penelitian ini diperoleh bahwa rata-rata hasil belajar post test mahasiswa yang memperoleh pembelajaran kooperatif tipe jigsaw sebesar 81,43 dan pada siswa yang diajarkan dengan pembelajaran langsung sebesar 67,32. Hal ini menunjukkan bahwa rata-rata hasil belajar post test mahasiswa yang memperoleh pembelajaran kooperatif tipe jigsaw lebih tinggi daripada siswa yang memperoleh pembelajaran langsung. Berdasarkan pengujian dengan menggunakan uji-t maka diperoleh hasil belajar mahasiswa dengan nilai signifikan (sig) $\alpha=0,00001$. Taraf nilai signifikan hasil belajar mahasiswa lebih kecil dari $\alpha=0,05$, maka dapat disimpulkan bahwa nilai rata-rata hasil belajar mahasiswa yang memperoleh pembelajaran kooperatif tipe jigsaw lebih tinggi daripada mahasiswa yang memperoleh pembelajaran langsung.

Salah satu faktor yang paling berpengaruh terhadap peningkatan hasil belajar mahasiswa adalah pembelajaran khususnya disini pembelajaran kooperatif tipe jigsaw. Pada pembelajaran kooperatif tipe jigsaw dimulai dari dosen menetapkan topik materi dan membagi topik tersebut menjadi beberapa subtopik materi. Selanjutnya, dosen membentuk kelompok belajar heterogen terdiri atas 5-6 orang mahasiswa dan membagikan materi yang akan dibahas pada masingmasing kelompok. Ketua kelompok kemudian membagikan materi kepada masing-masing kelompoknya untuk dipelajari secara individu terlebih dahulu. Langkah pembelajaran ini tentu akan membuat mahasiswa terlibat aktif dan mandiri dalam pembelajaran di kelas. Hal ini berbeda dengan langkah pada model pembelajaran langsung dimana dosen menyampaikan 
tujuan pembelajaran dan setelah itu menyampaikan materi pelajaran kepada mahasiswa. Hal ini tentu akan membuat mahasiswa menjadi pasif, pengetahuan yang dimiliki mahasiswa juga bergantung kepada dosen, serta mahasiswa menganggap dosen sebagai satu-satunya sumber belajar (Sholihah dan Mahmudi, 2015:178).

Langkah selanjutnya pada model pembelajaran kooperatif tipe jigsaw, mahasiswa dengan sub topik materi yang sama akan berkumpul dan membentuk kelompok ahli untuk membentuk persamaan persepsi dan mengkaji lebih dalam mengenai tugas yang diberikan kepada mereka. Pada saat berdiskusi masing-masing anggota tim ahli akan belajar untuk memecahkan masalah, menyampaikan pendapat, menerima perbedaan pendapat, mengajukan pertanyaan, menjawab pertanyaan dan menyiapkan materi yang akan dijelaskan pada kelompok asalnya. Hal tersebut tentu dapat meningkatkan kemampuan mahasiswa dalam pemecahan masalah, komunikasi serta kemampuan berpikir kritis mahasiswa. Pernyataan ini didukung oleh teori Slavin (2010) yang menyatakan bahwa mahasiswa yang belajar dalam kelompok akan memiliki prestasi yang lebih tinggi secara signifikan jika dibandingkan pada pembelajaran langsung. Pada pembelajaran langsung dosen hanya memberikan soal latihan kepada mahasiswa untuk dikerjakan baik secara mandiri. Pada tahap ini biasanya mahasiswa akan menerapkan pengetahuan yang diperoleh dari dosen dalam menyelesaikan latihan yang diberikan. Hal ini menyebabkan interaksi antar mahasiswa menjadi berkurang.

Pada langkah model pembelajaran kooperatif tipe jigsaw selanjutnya mahasiswa yang berada pada tim ahli akan kembali kepada kelompoknya asalnya masing-masing dan bertanggung jawab untuk menjelaskan materi bagiannya kepada anggota kelompoknya secara bergantian. Pada saat mahasiswa dapat mengajarkan suatu materi dengan teman sekelompoknya akan membuat mahasiswa dapat belajar secara efektif karena mahasiswa dapat lebih leluasa menjelaskan materi dengan teman sekelompoknya. Selain itu, mahasiswa juga dapat lebih leluasa dalam mengatur waktu pembelajaran, tujuan belajar yang dicapai dan target penguasaan materi yang diharapkan (Arjanggi \& Suprihatin, 2010: 95). Selain itu, pada tahap ini para anggota kelompok akan mengajukan pertanyaan terkait dengan materi yang telah dijelaskan dan saling bertukar pikiran dalam membentuk pemahaman mereka.Sedangkan pada tahap model pembelajaran langsung dosen akan mengecek pemahaman mahasiswa dan memberikan umpan balik dengan meminta beberapa orang mahasiswa menjelaskan atau menuliskan penyelesaian dari latihan yang diberikan oleh dosen di depan kelas. Hal ini terkadang menimbulkan kompetisi dan dominasi antar mahasiswa dimana mahasiswa yang memiliki kemampuan tinggi akan menunjukkan keahliannya dalam menyelesaikan permasalahan yang diberikan oleh dosen sedangkan mahasiswa dengan kemampuan rendah akan bersikap pasif dalam pembelajaran. Hal ini berdasarkan hasil penelitian Akramunnisa dan Sulestry (2016) yang menyatakan bahwa mahasiswa yang memiliki kemampuan awal yang tinggi akan mampu menganalisis masalah dengan baik, terurut, jelas dan analitis jika dibandingkan dengan mahasiswa yang memiliki kemampuan awal yang rendah.

Langkah terakhir pada model pembelajaran kooperatif tipe jigsaw dosen akan memberikan tes individu dan akan memberikan rewards kepada kelompok yang anggotanya mendapat nilai tertinggi. Hal ini tentu akan membuat mahasiswa termotivasi untuk belajar lebih giat untuk mendapatkan hasil belajar yang memuaskan dan setiap anggota kelompok akan saling membantu dalam memahami materi secara keseluruhan. Sedangkan pada tahap terakhir pembelajaran langsung yaitu dosen memberikan latihan mandiri kepada mahasiswa. Berdasarkan penjelasan di atas, terdapat perbedaan langkah-langkah pembelajaran antara model pembelajaran kooperatif tipe jigsaw dengan model pembelajaran langsung dalam hal mengontruksi pengetahuan mahasiswa. Proses pembelajaran tersebut mempengaruhi hasil belajar yang diperoleh oleh mahasiswa dimana hasil belajar mahasiswa yang memperoleh pembelajaran kooperatif tipe jigsaw lebih baik daripada hasil belajar mahasiswa yang memperoleh pembelajaran langsung. Hasil dalam penelitian ini juga didukung dengan penelitian terdahulu seperti Kurniawati, Budiyono, dan Saputro (2017), Saila (2016) serta Shoffa dan Suprapti (2017) yang menyatakan 
bahwa terdapat perbedaan yang signifikan hasil belajar mahasiswa yang diberi pembelajaran kooperatif tipe jigsaw dan mahasiswa yang diberi pembelajaran langsung.

\section{E. Kesimpulan}

Berdasarkan hasil dan pembahasan penelitian di atas diperoleh kesimpulan bahwa terdapat perbedaan hasil belajar yang signifikan antara mahasiswa yang menerapkan pembelajaran kooperatif tipe jigsaw dengan hasil belajar mahasiswa yang menerapkan model pembelajaran langsung. Selanjutnya, dapat disimpulkan rerata hasil belajar mahasiswa yang menerapkan pembelajaran kooperatif jigsaw lebih tinggi jika dibandingkan dengan rerata hasil belajar mahasiswa yang menerapkan pembelajaran langsung.

\section{DAFTAR PUSTAKA}

Abdullah, R. (2015). Urgensi penilaian hasil belajar berbasis kelas mata pelajaran IPS di madrasah tsanawiyah. Lantanida Journal, 3(2), 168-181.

Akramunnisa \& Sulestry, A. I. Analisis kemampuan menyelesaikan masalah matematika ditinjau dari kemampuan awal tinggi dan gaya kognitif field independent. Pedagogy : Jurnal Pendidikan Matematika, 1(2), 46-150.

Anderson, L.W., Krathwohl, D.R., Airasian, P.W., Cruickshank, K.A., Mayer, R.E., Pintrich, P.R., et al. (2001). A taxonomy for learning, teaching and assissing: A revision of bloom's taxonomy of educational objectives. New York: Longman.

Arends, R. I. (2012). Belajar untuk mengajar (2nd ed.).Terjemahan oleh Helly Prajitno Soetjipto dan Sri Mulyantini Soetjipto. 2008. Yogyakarta : Pustaka Pelajar.

Arikunto. (2010). Manajemen Penelitian. Jakarta : PT. Rineka Cipta.

Arjanggi, R. \& Suprihatin, T. (2010). Metode pembelajaran tutor teman sebaya meningkatkan hasil belajar berdasar regulasi diri. Makara, Sosial Humaniora, 14(2), 91-97.

Asmah. (2018). Penerapan model pembelajaran langsung untuk meningkatkan hasil belajar matematika mahasiswa kelas II SD negeri 016 Buluh Kasap. Jurnal Pajar (Pendidikan dan Pengajaran), 1(1). 110-114.

Astuti, R. D. \& Abadi, A. M. (2015). Keefektifan pembelajaran jigsaw dan TAI ditinjau dari kemampuan penalaran dan sikap belajar matematika mahasiswa. Jurnal Riset Pendidikan Matematika, 2(2). 235-250.

Baharun, H. (2015). Penerapan pembelajaran active learning untuk meningkatkan hasil belajar siswa di madrasah. Jurnal Pendidikan Pedagogik, 1(1), 34-46.

Handayani, E. S. (2018). Penerapan model pembelajaran kooperatif tipe jigsaw dengan peta konsep pada materi persamaan kuadrat ditinjau dari sikap ilmiah peserta didik kelas X SMA di Kabupaten Kudus. Jurnal Pendidikan Matematika, 1(1),17-27.

Isjoni. (2010). Pembelajaran kooperatif meningkatkan kecerdasan komunikasi antar peserta didik. Jakarta: Pustaka Pelajar.

Katili, F. (2017). Pengaruh model pembelajaran kooperatif tipe jigsaw dan kemampuan berpikir kritis peserta didik terhadap hasil belajar matematika di kelas X SMK negeri 1 Batudaa. Jurnal Riset dan Pengembangan Ilmu Pengetahuan, 2(2), 220-225.

Kurniawati, K. R. A., Budiyono, \& Saputro, D. R. S. (2017). Penerapan model pembelajaran kooperatif tipe jigsaw dan nht ditinjau dari kecerdasan interpersonal mahasiswa pada pokok bahasan bangun ruang sisi datar. Jurnal Pendidikan Matematika, 11(1), 15-27.

Lie, A. (2010). Cooperative learning. Jakarta: Penerbit Grasindo.

Mashudi. (2018). Strategi pembelajaran kooperatif jigsaw vs pembelajaran langsung. Jurnal Dudeena, 2(2), 149-162.

Muin, A., \& Ulfah, R. M. (2012). Meningkatkan hasil belajar matematika mahasiswa dengan pembelajaran menggunakan aplikasi moodle. Jurnal Phytagoras, 7(1). 73-82.

Nurfitriyanti, M. (2017). Pengaruh model pembelajaran kooperatif tipe jigsaw terhadap hasil belajar matematika ditinjau dari kecerdasan emosional. Jurnal Formatif, 7(2), 153-162. 
Republik Indonesia. (2012). Undang-Undang Republik Indonesia Nomor 12 Tahun 2012 tentang Perguruan Tinggi.

Riyanto, Y. (2010). Paradigma baru pembelajaran. Jakarta: Kencana Prenada Media Group.

Rosdiati. (2017). Upaya meningkatkan hasil belajar matematika melalui model pembelajaran kooperatif tipe STAD sekolah dasar. Suara Dosen: Jurnal Ilmu Pendidikan Sosial, Sains dan Humaniora, 3(2), 315-321.

Saila, N. (2016). Penerapan pembelajaran kooperatif tipe jigsaw pada perkuliahan matematika. Prosiding Seminar Nasional Pendidikan Matematika 2, Malang: 29 Mei 2016. Hal. 208216.

Shoffa, S. \& Suprarpti, E. (2017). Peningkatan hasil belajar mahasiswa pada mata kuliah metode numerik dengan model pembelajaran kooperatif jigsaw. MUST: Journal of Mathematics Education, Science and Technology, 2(2), 178-188.

Sholihah, D.A., dan Mahmudi, A. (2017). Keefektifan experiential learning pembelajaran matematika mts materi bangun ruang sisi datar. Jurnal Riset Pendidikan Matematika, 2(2), 175-185.

Slavin, R. E. (2010). Cooperative learning: Teori riset dan praktik. Bandung: Nusa Media .

Sudjana, N. (2010). Penilaian hasil proses belajar mengajar. Bandung: PT Remaja Rosdakarya.

Susanto, A. (2013). Teori belajar dan pembelajaran di sekolah dasar. Jakarta: Kencana Prenada Media Grup.

Susiaty, U. D. (2017). Penerapan model pembelajaran direct instruction (DI) terhadap prestasi belajar mahasiswa prodi pendidikan TIK IKIP PGRI Pontianak. EduSains: Jurnal Pendidikan Sains dan Matematika, 5(2). 33-38.

Suyatno. 2009. menjelajah pembelajaran inovatif. Surabaya: Masmedia Buana Pustaka.

Trianto. (2011). Mendesain model pembelajaran inovatif-progresif: konsep, landasan, dan implementasinya pada kurikulum tingkat satuan pendidikan. Jakarta: Kencana.

Wahyuningsih, T., Rezeki,S., \& Zetriuslita. (2013). Perbandingan hasil belajar matematika mahasiswa melalui penerapan model pembelajaran langsung dengan pembelajaran kooperatif. Jurnal Matematika, 3(2), 52-63.

Wibowo, I. S. \& Farnisa, R. (2018). Hubungan peran dosen dalam proses pembelajaran terhadap prestasi belajar mahasiswa. Jurnal Gentala Pendidikan Dasar, 3(2), 181-201.

Yamin, M. (2013). Strategi dan metode dalam model pembelajaran. Jakarta: Referensi (GP Press Group).

Yulianti, P. \& Fitri, M. E. Y. (2017). Evaluasi prestasi belajar mahasiswa terhadap perilaku belajar dan motivasi belajar mahasiswa di perdosenan tinggi kota padang provinsi sumatera barat. Jurnal Akuntasi, Ekonomi dan Manajemen Binis, 5(2). 242-251.

Yusuf, A. M. (2017). Assesmen dan evaluasi pendidikan. Jakarta: Kencana. 